Article

\title{
Development of a Pyrometer That Measures the True Temperature Field of the Two-Dimensional Array
}

\author{
Bojun Sun ${ }^{1} \oplus$, Xiaogang Sun ${ }^{1, *}$, Meisheng Luan ${ }^{2}$, Jingmin Dai ${ }^{1}$ and Shuanglong Cui ${ }^{1}$ \\ 1 School of Instrumentation Science and Engineering, Harbin Institute of Technology, No.92, Xidazhi Street, \\ Harbin 150001, China; sunbjhit@163.com (B.S.); djm@hit.edu.cn (J.D.); cslyingzi@163.com (S.C.) \\ 2 Library of HIT, Harbin Institute of Technology, No.92, Xidazhi Street, Harbin 150001, China; \\ ssxxllmm@163.com \\ * Correspondence: sxg@hit.edu.cn; Tel.: +86-13074589432
}

Received: 28 March 2020; Accepted: 17 April 2020; Published: 22 April 2020

\begin{abstract}
This paper develops a two-dimensional array pyrometer, which can measure the true temperature field of the two-dimensional array. The pyrometer consists of an optical part, a circuit part and a software part. In the optical part, the radiation energy of the two-dimensional array target is obtained by scanning with the rotating mirror. Then, the radiation signal is converted and amplified by the circuit part. The software component realizes the functions of the pyrometer calibration, signal acquisition and data processing. The data processing adopts the secondary measurement method to calculate the true temperature and uses the multi-threaded method to improve the operational efficiency. Experiments show that the uncertainty of the two-dimensional pyrometer array can reach $1.43 \%$. Compared with the single-threaded method, the true temperature operation time of the two-dimensional pyrometer array is improved by $77 \%$, which verifies that the software operational efficiency is greatly improved.
\end{abstract}

Keywords: two-dimensional array pyrometer; true temperature measurement; radiation energy; secondary measurement method

\section{Introduction}

Radiation thermometry [1-3] frequently uses a multi-wavelength pyrometer (MWP) [4-6] to overcome the restrictions from the unknown emissivity of traditional one-color pyrometers and the constant emissivity vs. wavelength for two-color ratio pyrometers [7,8]. A multi-wavelength pyrometer can obtain the true temperature of the target without emissivity information by using the principle of multi-wavelength radiation thermometry [9]. Gardner et al. developed a six-wavelength pyrometer with filter arrays for metal melting applications [10]. Hiernaut et al. developed a six-color pyrometer with a fiber-optic bundle [11]. Radousky and Mitchel developed an ultraviolet pyrometer to measure shock temperatures with a semi-transparent and semi-reflective mirror in 1989 [12]. Levendis et al. developed a three-color ratio pyrometer that employed one visible and two near-infrared wavelengths to measure the surface temperatures of burning carbonaceous particles [13]. Ng and Fralick explored a multi-wavelength pyrometer with a spectrometer to measure the true temperatures of transparent substances and combustion gases [14]. In 2017, Mei et al. developed a long-distance multi-wavelength pyrometer [15], which placed the core of the instrument $100 \mathrm{~m}$ from the probe.

The current multi-wavelength radiation pyrometers $[16,17]$ are all designed for single point or multi-point targets. This paper develops a multi-wavelength radiation pyrometer that can be used to measure the true temperature field of the two-dimensional array. It consists of an optical part, a circuit part and a software part. In the optical part, the data of the two-dimensional array are achieved by combining the longitudinal scanning by the rotating mirror with the transverse 
multi-target points' method. In this way, the hardware space resources are saved, and the operation process of data acquisition is simplified at the same time, illustrating that the hardware resources and the measurement speed are both considered. The circuit part includes an I/V conversion circuit, a V/V amplification circuit and a data acquisition card. The I/V conversion circuit uses AD820 to convert the signal into a voltage signal. The V/V amplification circuit uses OP07 to amplify the voltage signal. Finally, the pyrometer uses the USB5630 data acquisition card to obtain the voltage signal, so as to realize the information interaction between hardware circuit and upper computer. The software part is compiled by using Visual Studio as the development environment and using C\# as the language, mainly including the functions of pyrometer calibration, data acquisition and data processing. Data processing adopts a secondary measurement method to calculate true temperatures [18] and uses a multi-threaded method to improve the operation efficiency.

After the development of the pyrometer, this work carries out the uncertainty analysis and the two-dimensional array true temperature measurement experiment, and finally obtains the uncertainty of the two-dimensional array pyrometer.

\section{Principles of Measurement}

According to reference [18], a flow chart of the secondary measurement method is shown in Figure 1.

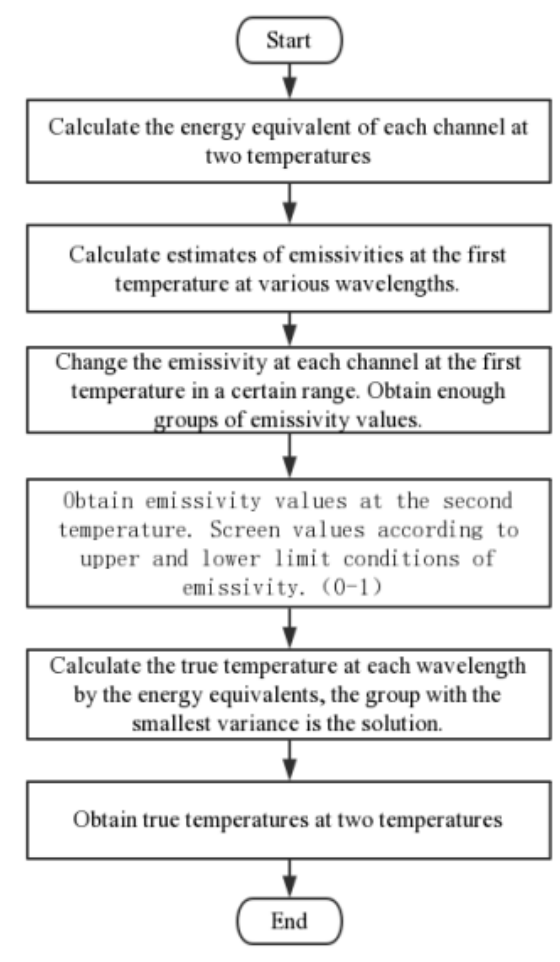

Figure 1. A flow chart of the secondary measurement method.

The principles of measurement are as follows [18]:

If the multi-wavelength pyrometer has $n$ spectral channels, the output signal $V_{i}$ of the $i$ th channel is defined as in Equation (1):

$$
V_{i}=A_{\lambda_{i}} \cdot \varepsilon\left(\lambda_{i}, T\right) \cdot\left(\frac{1}{\lambda_{i}{ }^{5}\left(e^{\frac{c_{2}}{\lambda_{i} T}}-1\right)}\right) \quad(i=1,2, \ldots, n)
$$


where $A_{\lambda_{i}}$ is a temperature-independent calibration constant, which is related to the wavelength, and is also related to the spectral responsiveness of the detector, the transmittance of the optical element, the geometric size at that wavelength and the first radiation constant; $\lambda_{i}$ is the effective wavelength of the $i$ th channel; $\varepsilon\left(\lambda_{i}, T\right)$ is the target spectral emissivity at temperature $T$; and $c_{2}$ is the second radiation constant, which is $14,388 \mu \mathrm{m} \cdot \mathrm{K}$.

Equation (1) can be rewritten into the form shown in Equation (2):

$$
V_{i}=A_{\lambda_{i}} \cdot \varepsilon\left(\lambda_{i}, T\right) \cdot \lambda_{i}{ }^{-5} \cdot e^{-\frac{c_{2}}{\lambda_{i} T}} \quad(i=1,2, \ldots, n)
$$

The output signal $V^{\prime}{ }_{i}$ of the $i$ th channel of blackbody is as follows:

$$
V_{i}^{\prime}=A_{\lambda_{i}} \cdot \lambda_{i}^{-5} \cdot e^{-\frac{c_{2}}{\lambda_{i} T^{\prime}}}\left[\varepsilon\left(\lambda_{i}, T\right) \text { is } 1.0 \text { here, so it is omitted. }\right]
$$

The ratio of Equations (2) and (3) is described by:

$$
\frac{V_{i}}{V_{i}^{\prime}}=\varepsilon\left(\lambda_{i}, T\right) \cdot e^{-\frac{c_{2}}{\lambda_{i} T}} \cdot e^{\frac{c_{2}}{\lambda_{i} T^{\prime}}}
$$

where $\frac{V_{i}}{V_{i}^{\prime}}$ is called the radiation energy equivalent of $i$ th channel.

Note $V_{i, 1}$ as the output signal of the $i$ th channel at the first temperature. Note $V_{i, 2}$ as the output signal of the $i$ th channel at the second temperature. Note $T_{1}^{0}$ as the estimated value of the first temperature. Then, the estimated emissivity $\varepsilon_{i, 1}^{0}$ of the $i$ th channel at the first temperature can be described as in Equation (5), according to Equation (4):

$$
\varepsilon_{i, 1}^{0}=\frac{V_{i, 1}}{V_{i}^{\prime}} \cdot e^{\frac{c_{2}}{\lambda_{i} T_{1}^{0}}} \cdot e^{-\frac{c_{2}}{\lambda_{i} T^{\prime}}}
$$

The emissivity at the second temperature $T_{2}$ is as follows:

$$
\varepsilon_{i}=\varepsilon_{i, 1}^{\prime}\left[1+k\left(T_{2}-T_{1}^{0}\right)\right]
$$

where $\varepsilon_{i, 1}^{\prime} \in\left(\varepsilon_{i, 1}^{0}-\varepsilon, \varepsilon_{i, 1}^{0}+\varepsilon\right), T_{2} \in\left(T_{1}^{0}-M, T_{1}^{0}+M\right), k \in(-\eta, \eta), \varepsilon>0, \eta>0, M>0$.

Note $T_{i, 2}$ as the calculated temperature of the $i$ th channel at the second temperature. According to Equation (4):

$$
T_{i, 2}=\frac{1}{\frac{1}{T^{\prime}}+\frac{\lambda_{i}}{c_{2}} \ln \frac{\varepsilon_{i} \cdot V_{i}^{\prime}}{V_{i, 2}}}
$$

Rewrite Equation (6) as follows:

$$
\varepsilon_{i}=\varepsilon_{i, 1}^{\prime}\left[1+k\left(T_{i, 2}-T_{1}^{0}\right)\right]
$$

Combine Equations (7) and (8):

$$
T_{i, 2}=\frac{1}{\frac{1}{T^{\prime}}+\frac{\lambda_{i}}{c_{2}} \ln \frac{\varepsilon_{i, 1}^{\prime}\left[1+k\left(T_{i, 2}-T_{1}^{0}\right)\right] \cdot V_{i^{\prime}}}{V_{i, 2}}}
$$

For the same reason, the calculated temperature of the $i$ th channel at the first temperature is as follows:

$$
T_{i, 1}=\frac{1}{\frac{1}{T^{\prime}}+\frac{\lambda_{i}}{c_{2}} \ln \frac{\varepsilon_{i, 1}^{0} \cdot V_{i^{\prime}}}{V_{i, 1}}}
$$


Equations (9) and (10) are $T_{i, l}(l=1,2)$-related equations, which can be solved by an iterative method. The criterion of the optimal solutions is to minimize the variance of $T_{i, 1}$ and $T_{i, 2}$ :

$$
\min F=\sum_{l=1}^{2} \sum_{i=1}^{n}\left[T_{i, l}-\frac{1}{n} \sum_{i=1}^{n} T_{i, l}\right]^{2}
$$

Based on formulas mentioned above, the optimal solution of the true temperatures can be obtained.

\section{Design of Pyrometer}

The block diagram and physical figure of the two-dimensional array pyrometer are shown in Figures 2 and 3 respectively. The pyrometer is mainly composed of an optical part, a circuit part and a software part. The radiation energy of the target will be transmitted to the rotating mirror of the optical part first. The optical part uses ten side-by-side optical fibers to transmit the radiated signal of the target. The circuit part receives the signals from the optical part for signal conversion and amplification, and then uses a USB5630 data acquisition card to collect data. At last, the USB5630 transmits the data to the PC for storage, processing and display. The pyrometer has a temperature measurement range of $1100-3000 \mathrm{~K}$, a measurement spectrum range of $0.525-0.980 \mu \mathrm{m}$, and a single channel acquisition rate of $100 \mathrm{kHz}$.

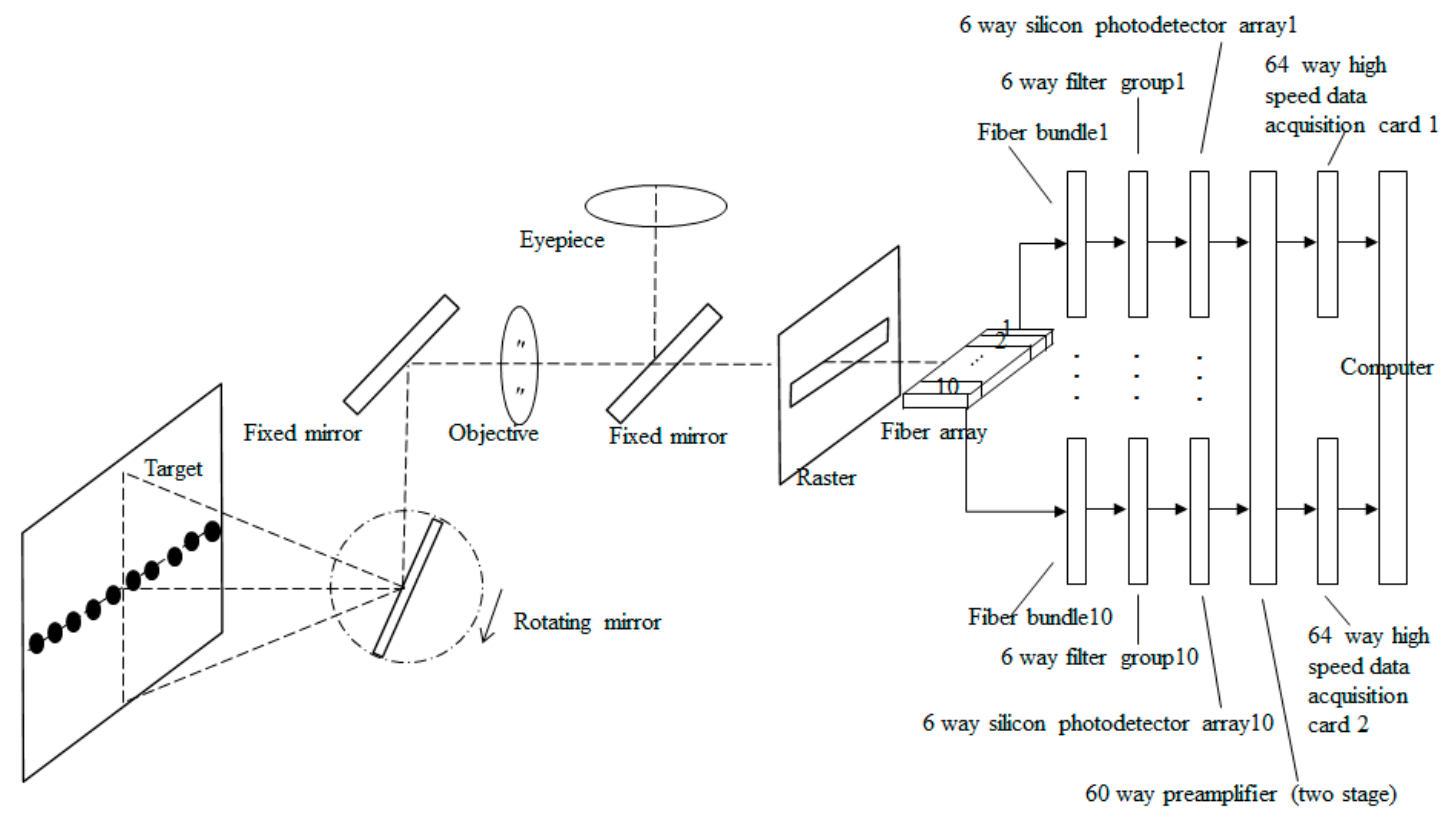

Figure 2. A block diagram of the two-dimensional array pyrometer.
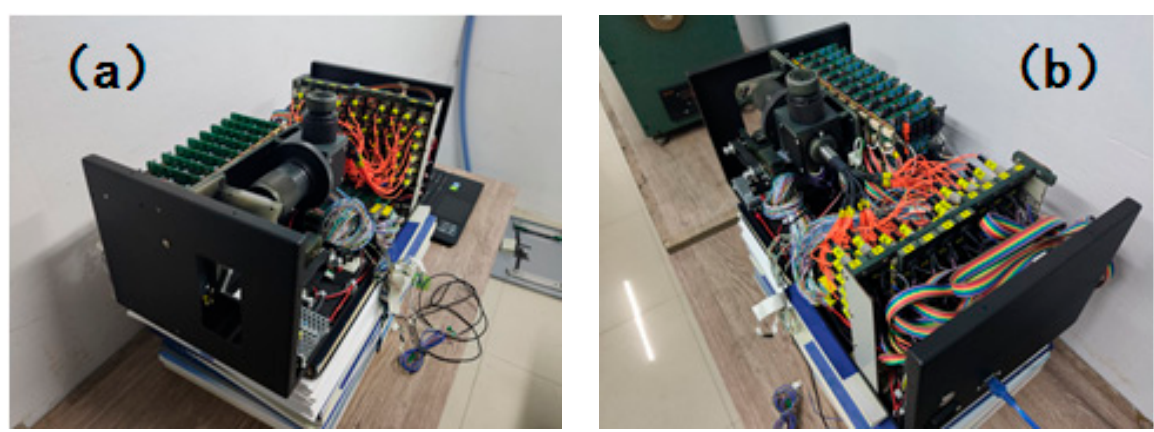

Figure 3. A physical figure of the two-dimensional array pyrometer: (a) front and (b) back. 


\subsection{Design of the Optical Part}

In the optical part, hardware resources will be saved but the measurement speed will be seriously reduced if the single point scanning scheme is adopted, whereas the measurement speed will be increased but the hardware resources requirements will be too large if the multi-point staring scheme is adopted. Therefore, the data acquisition function of the two-dimensional array pyrometer is realized by the cooperation of the longitudinal scanning by the rotating mirror and the transverse multi-target points' method. The target information of the two-dimensional array is composed of ten one-dimensional transverse target points side by side (black spots in Figure 2) and a rotating mirror changing the longitudinal position, so as to optimize the measurement speed and use of hardware resources.

\subsubsection{Subsection}

The radiation energy of the target is first transmitted to the rotating mirror. A structural schematic diagram of the rotating mirror is shown in Figure 4, and the physical figure is shown in Figure 5.

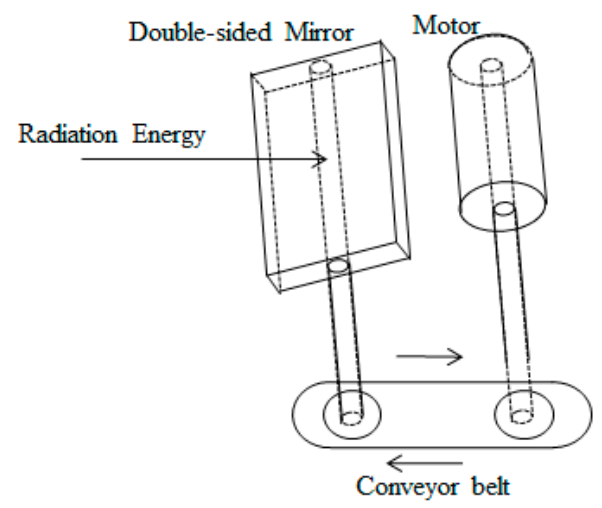

Figure 4. A structural schematic diagram of the rotating mirror.

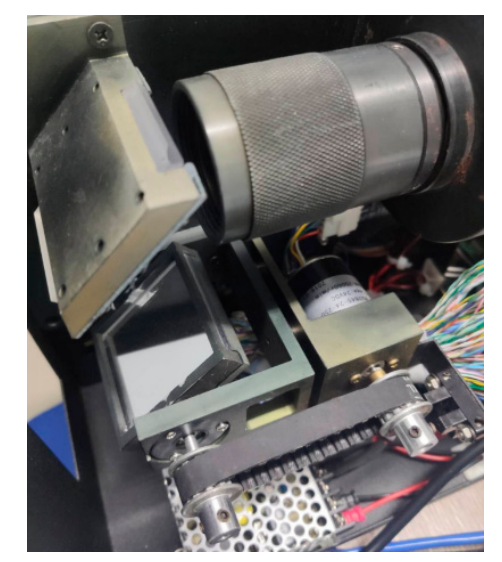

Figure 5. A physical figure diagram of the rotating mirror.

The motor drives the double-sided mirror to rotate clockwise through the conveyor belt and realizes the longitudinal scanning function of the target through the mirror rotation. The motor model is WS2845-24-250-1, and the speed is 25,000 $\mathrm{r} / \mathrm{min}$. The eyepiece above the rotating mirror is used for focusing and accurate observation. 


\subsubsection{Optical Fiber and Filter}

The radiation energy of the target enters the light receiving area of the optical fiber probe after passing through the rotating mirror, objective and raster. The light receiving area is divided for 10 targets, and there are 10 channels of optical fiber bundles connected behind the optical fiber probe to transmit the radiation energy under different targets. Respectively, 6-bunch optical fibers are connected to each channel to divide the radiation energy of each channel into six channels, and the six channels of radiation energy are respectively equipped with filters of different effective wavelengths to obtain energy information at the specific wavelengths. A schematic diagram of the optical fiber transmission structure with 10-channels-into-60-channels is shown in Figure 6. The effective wavelengths of each channel are shown in Table 1.

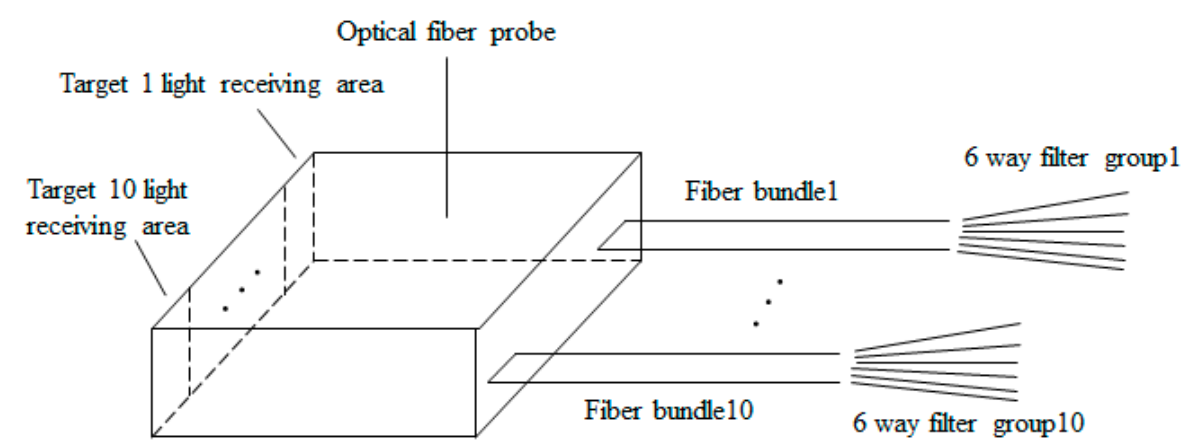

Figure 6. A schematic diagram of the optical fiber transmission structure.

Table 1. The effective wavelength of each channel.

\begin{tabular}{lcccccc}
\hline & Channel 1 & Channel 2 & Channel 3 & Channel 4 & Channel 5 & Channel 6 \\
\hline Wavelength $/ \mu \mathrm{m}$ & 0.525 & 0.635 & 0.700 & 0.808 & 0.903 & 0.980 \\
\hline
\end{tabular}

\subsection{Design of Circuit Part}

The function of the circuit part is to convert the radiation energy acquired by the optical part into a voltage signal. After passing through the optical fiber and filter, the energy signal enters the photoelectric detector, and then uses the I/V conversion circuit and V/V amplification circuit to amplify the signal. Finally, the pyrometer uses the high-speed data acquisition system to collect the data. The design of circuit part is shown in Figure 7.

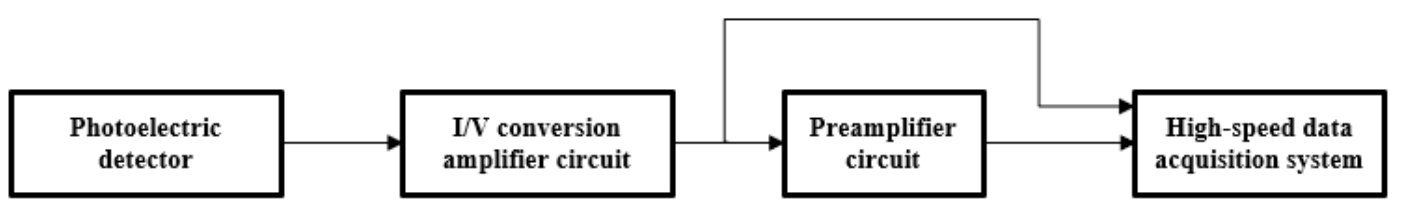

Figure 7. The design of the circuit part.

\subsubsection{Photoelectric Detector Array}

The photoelectric detector adopts a silicon photoelectric detector array. Each channel of the 60 channel optical fiber is connected with one silicon photodiode behind, i.e., a total of 60 silicon photoelectric detectors are used. The model of silicon photoelectric detector is S1336-5BK, with a spectral response range of $0.320-1.100 \mu \mathrm{m}$. The photosensitivity vs. wavelength dependence of S1336-5BK is shown in Figure 8 [19]. 


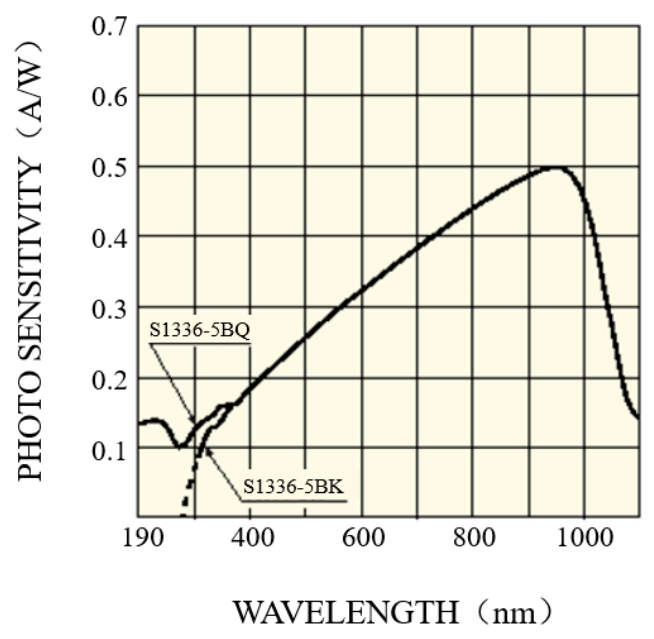

Figure 8. The photosensitivity vs. wavelength dependence of S1336-5BK.

\subsubsection{I/V Conversion Circuit and V/V Amplification Circuit}

A structure diagram of the $\mathrm{I} / \mathrm{V}$ conversion circuit and $\mathrm{V} / \mathrm{V}$ amplification circuit is shown in Figure 9. The selection range of the feedback resistance $R 2$ of the $I / V$ conversion circuit is $1-10 \mathrm{M} \Omega$ and the selection range of the feedback capacitance $\mathrm{Cf}$ is $1-10 \mathrm{pf}$. The selected operational amplifier model of the I/V conversion circuit is AD820. The 10 times V/V amplification circuit is built after the I/V conversion circuit, and the selected operational amplifier model of the $\mathrm{V} / \mathrm{V}$ amplification circuit is OP07.

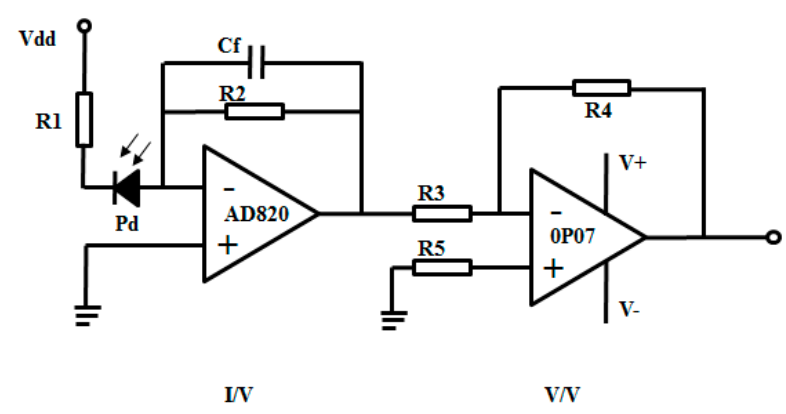

Figure 9. A structure diagram of the I/V conversion circuit and V/V amplification circuit.

\subsubsection{High-Speed Data Acquisition System}

The two-dimensional array pyrometer needs to collect the two-dimensional array temperature field information, including ten targets, and each target contains six channels. Each channel needs to collect two-stage voltage data (I/V conversion circuit and V/V amplification circuit) at the same time, so it needs to meet the demand of collecting 120 channels of signals at the same time. The maximum speed of a single channel needs to reach $100 \mathrm{kHz}$ during the acquisition process.

In this work, two USB5630 data acquisition cards are used to constitute the high-speed data acquisition system. A single USB5630 data acquisition card has 64 available channels, and we use a 64 single-ended analog inputs method here. The maximum acquisition voltage range can be $\pm 10 \mathrm{~V}$, $\pm 5 \mathrm{~V}, \pm 2.5 \mathrm{~V}, 0 \sim 10 \mathrm{~V}$ and $0 \sim 5 \mathrm{~V}$ (we use $\pm 10 \mathrm{~V}$ here), and the single channel acquisition rate can reach $500 \mathrm{kHz}$. The sampling is multiplexed here. The ADC resolution is 16 bits, and the voltage resolution can be $\frac{1}{2^{16}-1} * 20 \mathrm{~V} \approx 0.3 \mathrm{mV}$ here. USB or Ethernet can be chosen to transmit the acquisition data to achieve the function of data acquisition, storage and processing. In this work, Ethernet transmission is adopted, and the maximum transmission speed is $100 \mathrm{Mbps}$.

The physical figure of the USB5630 data acquisition card is shown in Figure 10. 

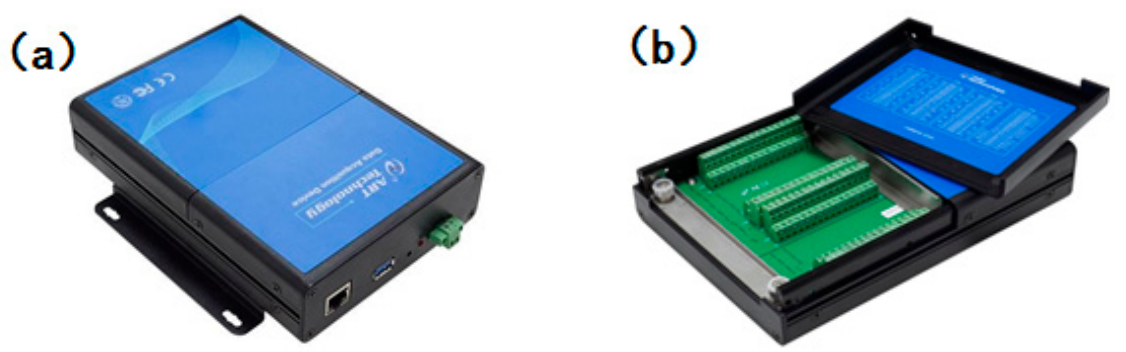

Figure 10. A physical figure of the USB5630 data acquisition card, (a) outside and (b) inside.

\subsection{Design of the Software Part}

The software part uses Visual Studio 2015 as the platform and C\# as the programming language for software development. All experiments in this paper use the same computer environment: Intel (R) Core (TM) i7-7700Hp @ $2.80 \mathrm{GHz}$.

The main purpose of the software system is to obtain the voltage data received by the data acquisition card and process the data to get the true temperatures of the target at different times. The software part mainly consists of pyrometer calibration, data acquisition and data processing. The flow chart of software part is shown in Figure 11.

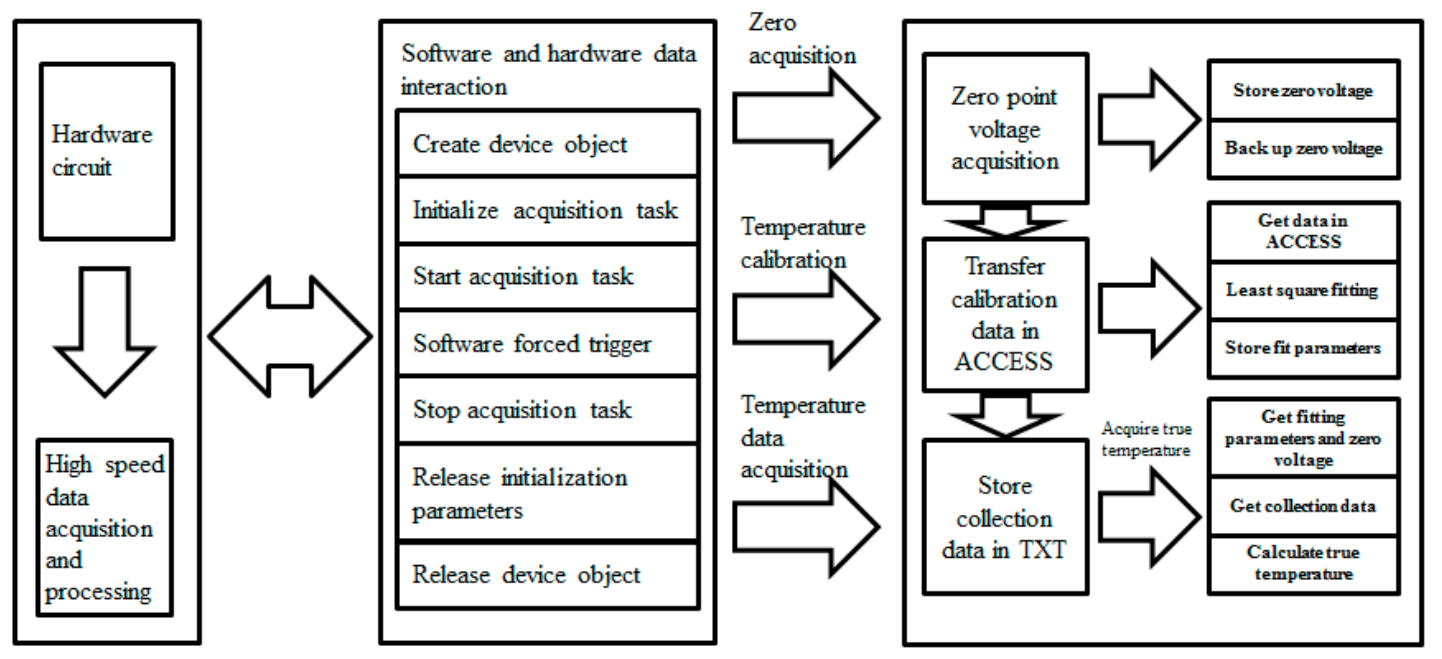

Figure 11. A flow chart of the software part.

The software part mainly includes three functions:

(1) Pyrometer Calibration: In the process of calibration, the ACCESS database is called to realize the storage of calibration temperature data. The process of calling ACCESS basics operations such as creation, design, connection, real-time change, disconnection, database closing and so on occurs. The real-time change of database includes insert, update, delete, query and other operations.

(2) Data Acquisition: When the high-speed data acquisition system collects data, it needs to transfer the voltage data in the buffer area into the txt file for storage, so as to prevent it from being overwritten by the next data. The implementation process includes creation, saving, modification, deletion, exit and other operations of the txt file.

(3) Data Processing: In the process of data processing, the energy equivalent information is obtained from the calculated voltage data and collected voltage data, and then the true temperature of the two-dimensional array target is calculated by the secondary measurement method. 


\section{Calibration}

The calibration procedure is as follows:

(1) Close the lens cover of the pyrometer;

(2) Take 500 samples of the output voltage data, take the average value, and get the zero voltage;

(3) Open the lens cover and aim the pyrometer at the window of the high temperature blackbody furnace, in which the temperature of the high temperature blackbody is measured with a standard pyrometer;

(4) When the temperature is constant, record the output voltage value and subtract the zero voltage;

(5) Record the data of the output voltage (after the subtraction of the zero voltage) and measured temperature in ACCESS.

The scene of field calibration is shown in Figure 12. When calling the calibration voltage data, the second stage data are called first. When the second stage data exceed $9900 \mathrm{mv}$, they are considered as saturation data, and then the first stage data are called. Through the process mentioned above, the pyrometer can obtain a curve of voltage vs. temperature and store the fit parameters.

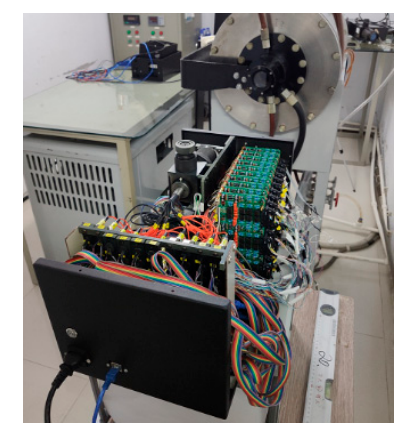

Figure 12. Field calibration.

\section{Uncertainty}

The uncertainty of the two-dimensional array pyrometer is obtained by three part synthesis: uncertainty of circuit $\mathrm{u}_{\mathrm{e}}$, uncertainty of calibration $\mathrm{u}_{\mathrm{c}}$, and uncertainty of true temperature construction $\mathrm{u}_{\varepsilon}$.

The combined uncertainty of the two-dimensional array pyrometer $u_{\text {Total }}$ is $u_{\text {Total }}=$ $\sqrt{\mathrm{u}_{\mathrm{e}}^{2}+\mathrm{u}_{\mathrm{c}}^{2}+\mathrm{u}_{\varepsilon}^{2}}$.

\subsection{Uncertainty of the Circuit}

The uncertainty of the circuit mainly comes from the temperature drift and the noise of the silicon photoelectric detector, the noise of the I/V conversion circuit and the noise of the V/V amplification circuit.

\subsubsection{Uncertainty of the Silicon Photoelectric Detector}

The equation for calculating the drift of the silicon photoelectric detector S1336-5BK is $\mathrm{u}_{\mathrm{etw}}=$ $\mathrm{K}_{\mathrm{T}} \cdot \Delta \mathrm{T}$ [17]; where $\Delta \mathrm{T}= \pm 2 \mathrm{~K}$ and $\mathrm{K}_{\mathrm{T}}=0.05 \%$, $\mathrm{u}_{\text {etw }}$ is $\pm 0.10 \%$.

The noise of the silicon photoelectric detector mainly derives from shot noise and thermal noise $[18,20]$.

Shot noise is generated by the PN junction random current of the silicon photoelectric detector and is evaluated according to $\mathrm{I}_{\text {etzs }}=\sqrt{2 \mathrm{qI}_{\mathrm{s}} \Delta \mathrm{f}}$ (where $\mathrm{q}$ is the electric charge $1.6 * 10^{-19} \mathrm{C}$, diode working bandwidth $\Delta \mathrm{f}=1 \mathrm{MHz}$, and $\mathrm{I}_{\mathrm{s}}=10^{-7} \mathrm{~A}$ ).

Thermal noise is generated by the free electron thermal motion of the silicon photoelectric detector and is calculated by $\mathrm{I}_{\mathrm{etzr}}=\sqrt{\frac{4 \mathrm{KT} \Delta \mathrm{f}}{\mathrm{R}_{\mathrm{sh}}}}$ (where $\mathrm{K}$ is the Boltzmann constant and $\mathrm{R}_{\mathrm{sh}}=10^{9}$ is the bypass resistance). 
Therefore, the uncertainty of the noise is $\mathrm{u}_{\mathrm{etz}}=\frac{\sqrt{\mathrm{I}_{\mathrm{etzr}}^{2}+\mathrm{I}_{\mathrm{etzr}}{ }^{2}}}{\mathrm{I}_{\mathrm{s}}} \approx 0.17 \%$.

The uncertainty of the silicon photoelectric detector is $\mathrm{u}_{\mathrm{et}}=\sqrt{\mathrm{u}_{\mathrm{etw}}^{2}+\mathrm{u}_{\mathrm{etz}}{ }^{2}} \approx 0.20 \%$.

\subsubsection{Uncertainty of the I/V Conversion Circuit and V/V Amplification Circuit}

The uncertainty of the I/V conversion circuit is based on AD820, and its temperature drift is calculated by $u_{\text {ea } 1}=\left[\frac{\Delta \mathrm{e}_{o s}}{\Delta \mathrm{T}}\left(\frac{R_{\mathrm{f1}}+\mathrm{R}_{\mathrm{sh}}}{\mathrm{R}_{\mathrm{f} 1} \mathrm{R}_{\mathrm{sh}}}\right)+\frac{\Delta \mathrm{I}_{\mathrm{b}}}{\Delta \mathrm{T}}\right] \frac{\Delta \mathrm{T}}{\mathrm{I}_{\mathrm{s}}}[15]$ (where $\frac{\Delta \mathrm{e}_{\mathrm{os}}}{\Delta \mathrm{T}}=2 \mu \mathrm{V} / \mathrm{K}$ is the voltage drift when the temperature change is $1 \mathrm{~K}$, the current drift is $\frac{\Delta \mathrm{I}_{\mathrm{b}}}{\Delta \mathrm{T}}=2 \mathrm{pA} / \mathrm{K}$, and the feedback resistance of the first stage amplifier is $R_{\mathrm{f} 1}=10 \mathrm{M} \Omega$. When $\mathrm{I}_{\mathrm{s}}=10^{-8} \mathrm{~A}$ and $\mathrm{R}_{\mathrm{sh}}=10^{9} \Omega, \mathrm{u}_{\mathrm{ea} 1} \approx 0.04 \%$.

The uncertainty of the $\mathrm{V} / \mathrm{V}$ amplification circuit is based on OP07, and its temperature drift is calculated by $u_{\mathrm{ea} 2}=\left[\frac{\Delta \mathrm{e}_{\mathrm{os}}}{\Delta \mathrm{T}}\left(\frac{\mathrm{R}_{\mathrm{f}}+\mathrm{R}_{2}}{\mathrm{R}_{\mathrm{f} 2}}\right)+\frac{\Delta \mathrm{I}_{\mathrm{b}}}{\Delta \mathrm{T}} \mathrm{R}_{2}\right] \frac{\Delta \mathrm{T}}{\mathrm{V}_{\mathrm{s}}}$ [15] (where the input resistance of the second stage is $R_{2}=50 \mathrm{~K} \Omega$, the input voltage is $\mathrm{V}_{\mathrm{s}}=5 \mathrm{mV}$, and the feedback resistance is $R_{\mathrm{f} 2}=500 \mathrm{~K} \Omega$. When $\frac{\Delta \mathrm{e}_{\text {os }}}{\Delta \mathrm{T}}=1.3 \mu \mathrm{V} / \mathrm{K}$ and neglecting $\frac{\Delta \mathrm{I}_{\mathrm{b}}}{\Delta \mathrm{T}}, \mathrm{u}_{\mathrm{ea} 2} \approx 0.057 \%$.

According to the data from ART company's technician, the uncertainty of USB5630 is $u_{A D}=0.1 \%$.

In conclusion, the total uncertainty of the circuit is $\mathrm{u}_{\mathrm{e}}=\sqrt{\mathrm{u}_{\mathrm{et}}^{2}+\mathrm{u}_{\mathrm{ea} 1}{ }^{2}+\mathrm{u}_{\mathrm{ea} 2}{ }^{2}+\mathrm{u}_{\mathrm{AD}}{ }^{2}} \approx 0.23 \%$.

\subsection{Uncertainty of the Calibration}

The emissivity of the high temperature blackbody furnace in the calibration experiment is 0.990 . The temperature deviation is less than 2 K. [18] The standard pyrometer and cavity blackbody furnace are used in the calibration process, and the quantization error is not higher than $0.3 \%$. [21]

According to the calibration results, the uncertainty of the calibration is $\mathrm{u}_{\mathrm{c}}=1.00 \%$.

\subsection{Uncertainty of the True Temperature Construction}

In this work, the method used in the construction of true temperature is the secondary measurement method. According to reference [15], the uncertainty of the true temperature construction is $\mathrm{u}_{\varepsilon}=$ $1.00 \%$.

\subsection{Combined Uncertainty}

All the uncertainty causes analyzed above are added in quadrature, leading to the combined uncertainty of the two-dimensional array pyrometer being $\mathrm{u}_{\text {Total }}=\sqrt{\mathrm{u}_{\mathrm{e}}{ }^{2}+\mathrm{u}_{\mathrm{c}}{ }^{2}+\mathrm{u}_{\varepsilon}{ }^{2}} \approx 1.43 \%$.

\section{Actual Measurement Experiment}

The two-dimensional array pyrometer designed in this work is used to carry out the actual measurement experiment on a high-temperature furnace. The temperature of the high-temperature furnace is adjusted to $1273 \mathrm{~K}$. The scene of the actual measurement experiment is shown in Figure 13. The data of the two-dimensional array target (high-temperature furnace) are composed of the data of a total of 100 target points with ten longitudinal axes (target1-target10) at ten time points. The ten time points (time1-time10) are 49.46, 49.49, 49.53, 49.58, 49.61, 49.65, 49.68, 49.71, 49.75 and $49.81 \mathrm{~s}$ after the start of the measurement. The energy equivalent measured by the pyrometer is shown in Figure 14 . The true temperature is calculated by the software part, and the true temperature measurement results of the two-dimensional array target are shown in Table 2. The true temperature operation time of the two-dimensional array pyrometer is shown in Table 3. 


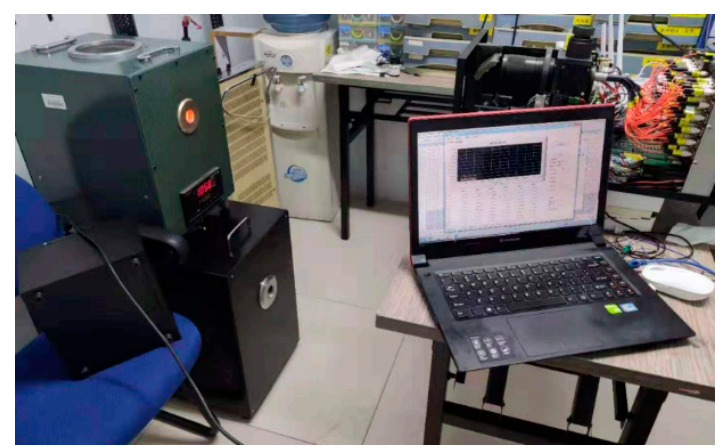

Figure 13. The actual measurement experiment.
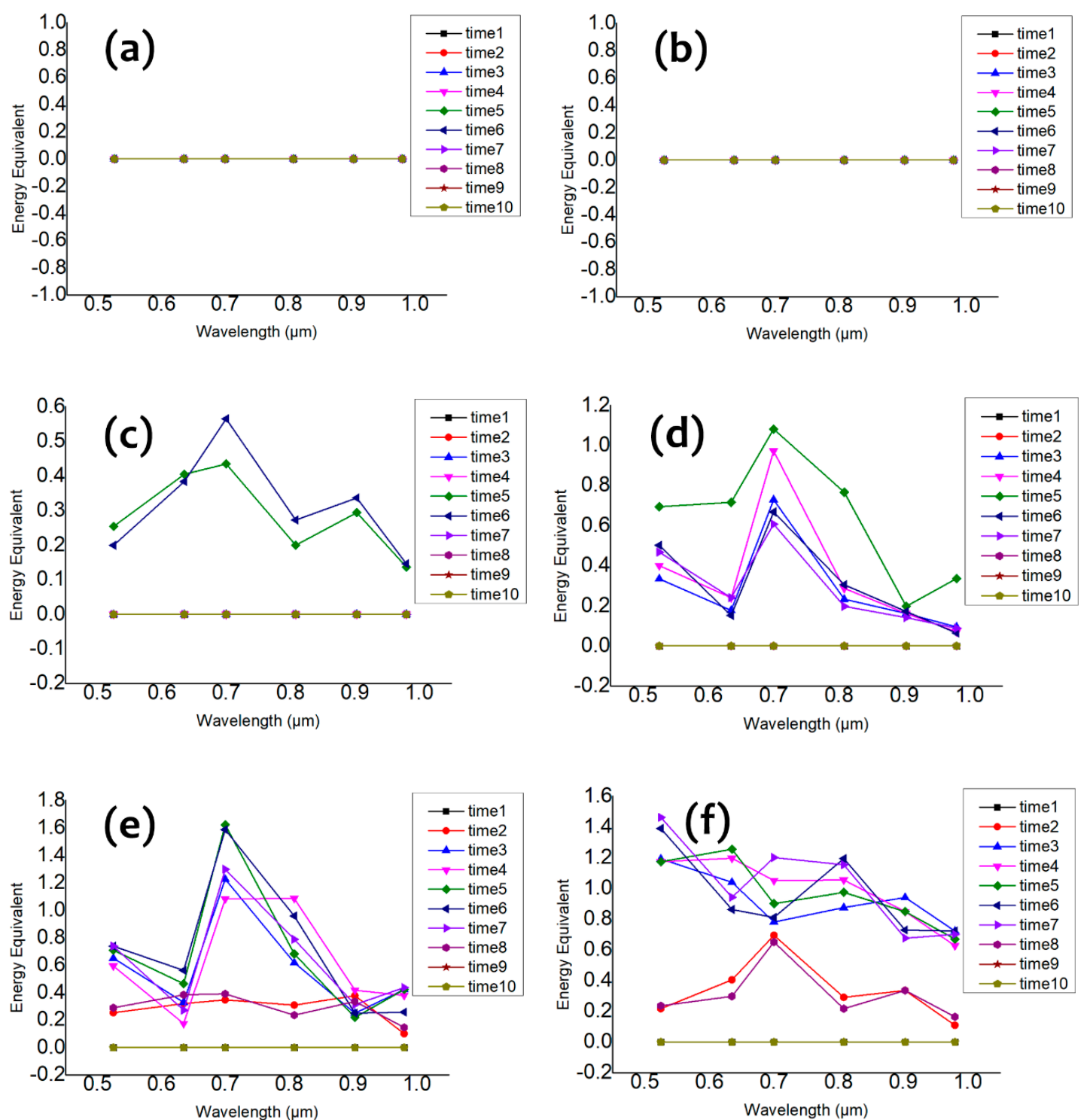

Figure 14. Cont. 

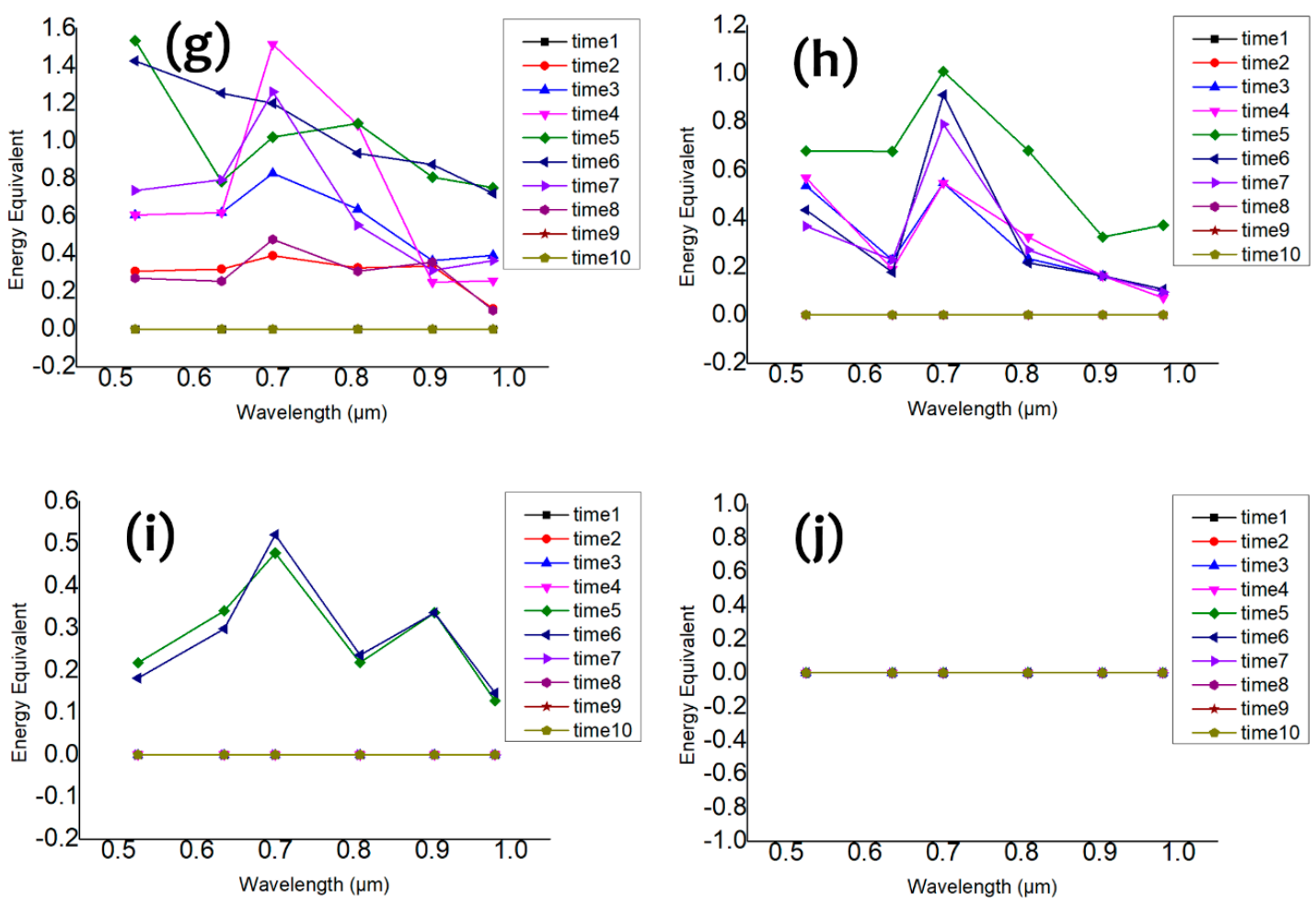

Figure 14. The energy equivalent of the high-temperature furnace (a-j), respectively, for target1-target10.

Table 2. The true temperature measurement results.

\begin{tabular}{|c|c|c|c|c|c|c|c|c|c|c|}
\hline & \multicolumn{10}{|c|}{ True Temperature of Each Target/K } \\
\hline & $\begin{array}{c}\text { Target } \\
1\end{array}$ & $\begin{array}{c}\text { Target } \\
2\end{array}$ & $\begin{array}{c}\text { Target } \\
3\end{array}$ & $\begin{array}{c}\text { Target } \\
4\end{array}$ & $\begin{array}{c}\text { Target } \\
5\end{array}$ & $\begin{array}{c}\text { Target } \\
6\end{array}$ & $\begin{array}{c}\text { Target } \\
7\end{array}$ & $\begin{array}{c}\text { Target } \\
8\end{array}$ & $\begin{array}{c}\text { Target } \\
9\end{array}$ & $\begin{array}{c}\text { Target } \\
10\end{array}$ \\
\hline Time1 & $\begin{array}{c}\text { no } \\
\text { value }\end{array}$ & $\begin{array}{c}\text { no } \\
\text { value }\end{array}$ & $\begin{array}{c}\text { no } \\
\text { value }\end{array}$ & $\begin{array}{c}\text { no } \\
\text { value }\end{array}$ & $\begin{array}{c}\text { no } \\
\text { value }\end{array}$ & $\begin{array}{c}\text { no } \\
\text { value }\end{array}$ & $\begin{array}{c}\text { no } \\
\text { value }\end{array}$ & $\begin{array}{c}\text { no } \\
\text { value }\end{array}$ & $\begin{array}{c}\text { no } \\
\text { value }\end{array}$ & $\begin{array}{c}\text { no } \\
\text { value }\end{array}$ \\
\hline Time2 & $\begin{array}{c}\text { no } \\
\text { value }\end{array}$ & $\begin{array}{c}\text { no } \\
\text { value }\end{array}$ & $\begin{array}{c}\text { no } \\
\text { value }\end{array}$ & $\begin{array}{c}\text { no } \\
\text { value }\end{array}$ & 1136.6 & 1174.1 & 1150.1 & $\begin{array}{c}\text { no } \\
\text { value }\end{array}$ & $\begin{array}{c}\text { no } \\
\text { value }\end{array}$ & $\begin{array}{c}\text { no } \\
\text { value }\end{array}$ \\
\hline Time3 & $\begin{array}{c}\text { no } \\
\text { value }\end{array}$ & $\begin{array}{c}\text { no } \\
\text { value }\end{array}$ & $\begin{array}{c}\text { no } \\
\text { value }\end{array}$ & 1185.3 & 1264.9 & 1264.1 & 1231.1 & 1186.8 & $\begin{array}{c}\text { no } \\
\text { value }\end{array}$ & $\begin{array}{c}\text { no } \\
\text { value }\end{array}$ \\
\hline Time4 & $\begin{array}{c}\text { no } \\
\text { value }\end{array}$ & $\begin{array}{c}\text { no } \\
\text { value }\end{array}$ & $\begin{array}{c}\text { no } \\
\text { value }\end{array}$ & 1197.5 & 1256.6 & 1267.7 & 1272.8 & 1180.4 & $\begin{array}{c}\text { no } \\
\text { value }\end{array}$ & $\begin{array}{c}\text { no } \\
\text { value }\end{array}$ \\
\hline Time5 & $\begin{array}{c}\text { no } \\
\text { value }\end{array}$ & $\begin{array}{c}\text { no } \\
\text { value }\end{array}$ & 1151.6 & 1248.7 & 1285.4 & 1271.1 & 1281.8 & 1243.5 & 1155.6 & $\begin{array}{c}\text { no } \\
\text { value }\end{array}$ \\
\hline Time6 & $\begin{array}{c}\text { no } \\
\text { value }\end{array}$ & $\begin{array}{c}\text { no } \\
\text { value }\end{array}$ & 1167.6 & 1189.8 & 1281.2 & 1281.1 & 1273.2 & 1212.0 & 1162.2 & $\begin{array}{c}\text { no } \\
\text { value }\end{array}$ \\
\hline Time7 & $\begin{array}{c}\text { no } \\
\text { value }\end{array}$ & $\begin{array}{c}\text { no } \\
\text { value }\end{array}$ & $\begin{array}{c}\text { no } \\
\text { value }\end{array}$ & 1172.7 & 1271.8 & 1277.7 & 1265.3 & 1190.2 & $\begin{array}{c}\text { no } \\
\text { value }\end{array}$ & $\begin{array}{c}\text { no } \\
\text { value }\end{array}$ \\
\hline Time8 & $\begin{array}{c}\text { no } \\
\text { value }\end{array}$ & $\begin{array}{c}\text { no } \\
\text { value }\end{array}$ & $\begin{array}{c}\text { no } \\
\text { value }\end{array}$ & $\begin{array}{c}\text { no } \\
\text { value }\end{array}$ & 1157.2 & 1188.3 & 1166.9 & $\begin{array}{c}\text { no } \\
\text { value }\end{array}$ & $\begin{array}{c}\text { no } \\
\text { value }\end{array}$ & $\begin{array}{c}\text { no } \\
\text { value }\end{array}$ \\
\hline Time9 & $\begin{array}{c}\text { no } \\
\text { value }\end{array}$ & $\begin{array}{c}\text { no } \\
\text { value }\end{array}$ & $\begin{array}{c}\text { no } \\
\text { value }\end{array}$ & $\begin{array}{c}\text { no } \\
\text { value }\end{array}$ & $\begin{array}{c}\text { no } \\
\text { value }\end{array}$ & $\begin{array}{c}\text { no } \\
\text { value }\end{array}$ & $\begin{array}{c}\text { no } \\
\text { value }\end{array}$ & $\begin{array}{c}\text { no } \\
\text { value }\end{array}$ & $\begin{array}{c}\text { no } \\
\text { value }\end{array}$ & $\begin{array}{c}\text { no } \\
\text { value }\end{array}$ \\
\hline Time10 & $\begin{array}{c}\text { no } \\
\text { value }\end{array}$ & $\begin{array}{c}\text { no } \\
\text { value }\end{array}$ & $\begin{array}{c}\text { no } \\
\text { value }\end{array}$ & $\begin{array}{c}\text { no } \\
\text { value }\end{array}$ & $\begin{array}{c}\text { no } \\
\text { value }\end{array}$ & $\begin{array}{c}\text { no } \\
\text { value }\end{array}$ & $\begin{array}{c}\text { no } \\
\text { value }\end{array}$ & $\begin{array}{c}\text { no } \\
\text { value }\end{array}$ & $\begin{array}{c}\text { no } \\
\text { value }\end{array}$ & $\begin{array}{c}\text { no } \\
\text { value }\end{array}$ \\
\hline
\end{tabular}


Table 3. The true temperature operation time.

\begin{tabular}{|c|c|c|c|c|c|c|c|c|c|c|}
\hline & \multicolumn{10}{|c|}{ Operation Time/ms } \\
\hline & $\begin{array}{c}\text { Target } \\
1\end{array}$ & $\begin{array}{c}\text { Target } \\
2\end{array}$ & $\begin{array}{c}\text { Target } \\
3\end{array}$ & $\begin{array}{c}\text { Target } \\
4\end{array}$ & $\begin{array}{c}\text { Target } \\
5\end{array}$ & $\begin{array}{c}\text { Target } \\
6\end{array}$ & $\begin{array}{c}\text { Target } \\
7\end{array}$ & $\begin{array}{c}\text { Target } \\
8\end{array}$ & $\begin{array}{c}\text { Target } \\
9\end{array}$ & $\begin{array}{c}\text { Target } \\
\mathbf{1 0}\end{array}$ \\
\hline Time1 & $\begin{array}{c}\text { no } \\
\text { value }\end{array}$ & $\begin{array}{c}\text { no } \\
\text { value }\end{array}$ & $\begin{array}{c}\text { no } \\
\text { value }\end{array}$ & $\begin{array}{c}\text { no } \\
\text { value }\end{array}$ & $\begin{array}{c}\text { no } \\
\text { value }\end{array}$ & $\begin{array}{c}\text { no } \\
\text { value }\end{array}$ & $\begin{array}{c}\text { no } \\
\text { value }\end{array}$ & $\begin{array}{c}\text { no } \\
\text { value }\end{array}$ & $\begin{array}{c}\text { no } \\
\text { value }\end{array}$ & $\begin{array}{c}\text { no } \\
\text { value }\end{array}$ \\
\hline Time2 & $\begin{array}{c}\text { no } \\
\text { value }\end{array}$ & $\begin{array}{c}\text { no } \\
\text { value }\end{array}$ & $\begin{array}{c}\text { no } \\
\text { value }\end{array}$ & $\begin{array}{c}\text { no } \\
\text { value }\end{array}$ & 210.07 & 263.776 & 227.124 & $\begin{array}{c}\text { no } \\
\text { value }\end{array}$ & $\begin{array}{c}\text { no } \\
\text { value }\end{array}$ & $\begin{array}{c}\text { no } \\
\text { value }\end{array}$ \\
\hline Time3 & $\begin{array}{c}\text { no } \\
\text { value }\end{array}$ & $\begin{array}{c}\text { no } \\
\text { value }\end{array}$ & $\begin{array}{c}\text { no } \\
\text { value }\end{array}$ & 159.530 & 224.23 & 220.786 & 212.759 & 192.015 & $\begin{array}{c}\text { no } \\
\text { value }\end{array}$ & $\begin{array}{c}\text { no } \\
\text { value }\end{array}$ \\
\hline Time4 & $\begin{array}{c}\text { no } \\
\text { value }\end{array}$ & $\begin{array}{c}\text { no } \\
\text { value }\end{array}$ & $\begin{array}{c}\text { no } \\
\text { value }\end{array}$ & 148.854 & 213.155 & 258.888 & 205.867 & 183.006 & $\begin{array}{c}\text { no } \\
\text { value }\end{array}$ & $\begin{array}{c}\text { no } \\
\text { value }\end{array}$ \\
\hline Time5 & $\begin{array}{c}\text { no } \\
\text { value }\end{array}$ & $\begin{array}{c}\text { no } \\
\text { value }\end{array}$ & 263.700 & 148.750 & 227.274 & 291.130 & 173.583 & 181.484 & 138.459 & $\begin{array}{c}\text { no } \\
\text { value }\end{array}$ \\
\hline Time6 & $\begin{array}{c}\text { no } \\
\text { value }\end{array}$ & $\begin{array}{c}\text { no } \\
\text { value }\end{array}$ & 304.769 & 234.414 & 219.112 & 287.03 & 197.443 & 152.904 & 85.938 & $\begin{array}{c}\text { no } \\
\text { value }\end{array}$ \\
\hline Time7 & $\begin{array}{c}\text { no } \\
\text { value }\end{array}$ & $\begin{array}{c}\text { no } \\
\text { value }\end{array}$ & $\begin{array}{c}\text { no } \\
\text { value }\end{array}$ & 241.907 & 216.698 & 255.736 & 146.963 & 158.437 & $\begin{array}{c}\text { no } \\
\text { value }\end{array}$ & $\begin{array}{c}\text { no } \\
\text { value }\end{array}$ \\
\hline Time8 & $\begin{array}{c}\text { no } \\
\text { value }\end{array}$ & $\begin{array}{c}\text { no } \\
\text { value }\end{array}$ & $\begin{array}{c}\text { no } \\
\text { value }\end{array}$ & $\begin{array}{c}\text { no } \\
\text { value }\end{array}$ & 205.244 & 213.274 & 138.696 & $\begin{array}{c}\text { no } \\
\text { value }\end{array}$ & $\begin{array}{c}\text { no } \\
\text { value }\end{array}$ & $\begin{array}{c}\text { no } \\
\text { value }\end{array}$ \\
\hline Time9 & $\begin{array}{c}\text { no } \\
\text { value }\end{array}$ & $\begin{array}{c}\text { no } \\
\text { value }\end{array}$ & $\begin{array}{c}\text { no } \\
\text { value }\end{array}$ & $\begin{array}{c}\text { no } \\
\text { value }\end{array}$ & $\begin{array}{c}\text { no } \\
\text { value }\end{array}$ & $\begin{array}{c}\text { no } \\
\text { value }\end{array}$ & $\begin{array}{c}\text { no } \\
\text { value }\end{array}$ & $\begin{array}{c}\text { no } \\
\text { value }\end{array}$ & $\begin{array}{c}\text { no } \\
\text { value }\end{array}$ & $\begin{array}{c}\text { no } \\
\text { value }\end{array}$ \\
\hline Time10 & $\begin{array}{c}\text { no } \\
\text { value }\end{array}$ & $\begin{array}{c}\text { no } \\
\text { value }\end{array}$ & $\begin{array}{c}\text { no } \\
\text { value }\end{array}$ & $\begin{array}{c}\text { no } \\
\text { value }\end{array}$ & $\begin{array}{c}\text { no } \\
\text { value }\end{array}$ & $\begin{array}{c}\text { no } \\
\text { value }\end{array}$ & $\begin{array}{c}\text { no } \\
\text { value }\end{array}$ & $\begin{array}{c}\text { no } \\
\text { value }\end{array}$ & $\begin{array}{c}\text { no } \\
\text { value }\end{array}$ & $\begin{array}{c}\text { no } \\
\text { value }\end{array}$ \\
\hline
\end{tabular}

Table 2 shows that the uncertainty of the two-dimensional array pyrometer can reach $1.43 \%$.

In this paper, the software data processing part adopts multi-threaded parallel processing. The 100 true temperature operation processes are carried out at the same time. Therefore, the maximum value of the operation time in Table 3 is the total time required for the true temperature operation process of the two-dimensional array pyrometer, which is $304.769 \mathrm{~ms}$, while the total true temperature operation time of the 100 target points with the single-threaded method is $1330.220 \mathrm{~ms}$. The time used by the multi-threaded method is $77 \%$ less than that used by the single-threaded method. Additionally, the two-dimensional array pyrometer can directly scan and measure the true temperature of the two-dimensional array target without complicated positioning operations, which greatly simplifies the operation and improves the practicability of the two-dimensional array pyrometer.

\section{Conclusions}

The uncertainty of the two-dimensional array pyrometer designed in this paper is $1.43 \%$. The pyrometer uses a combination of multi-target and mirror rotation scanning to achieve fast acquisition of the two-dimensional array target data. During data acquisition, the pyrometer does not need to be moved. Compared with general single-target and multi-target pyrometers, the operation process is greatly simplified. At the same time, the two-dimensional array pyrometer uses multi-threaded parallel processing, and the true temperature operation time is reduced by $77 \%$ compared with that for single-threaded, which improves the software operation efficiency.

Author Contributions: Conceptualization and writing-original draft preparation, B.S.; methodology, B.S.; software, B.S.; validation, X.S. and J.D.; visualization, M.L. and S.C.; funding acquisition, X.S. All authors have read and agreed to the published version of the manuscript.

Funding: This research was funded by National Natural Science Foundation of China (NSFC), grant number 61875046.

Conflicts of Interest: The authors declare no conflict of interest. 


\section{References}

1. Cao, G.; Weber, S.; Martin, S.; Sridharan, K.; Anderson, M.; Allen, T. Spectral emissivity of candidate alloys for very high temperature reactors in high temperature air environment. J. Nucl. Mater. 2013, 441, 667-673. [CrossRef]

2. Jani, M.A. Material Temperature Measurement Using Non-contacting Method. In Advanced Materials: Manufacturing, Physics, Mechanics and Applications; Springer International Publishing: Cham, Switzerland, 2016; pp. 357-362.

3. Esen, M.; Yuksel, T. Experimental evaluation of using various renewable energy sources for heating a greenhouse. Energy Build. 2013, 65, 340-351. [CrossRef]

4. Khan, M.A.; Allemand, C.; Eagar, T.W. Noncontact temperature measurement. ii. Least squares based techniques. Rev. Sci. Instrum. 1991, 62, 403-409. [CrossRef]

5. Hagqvist, P.; Sikstrm, F.; Christiansson, A.-K.; Lennartson, B. Emissivity compensated spectral pyrometryalgorithm and sensitivity analysis. Meas. Sci. Technol. 2014, 25, 025011. [CrossRef]

6. Xing, J.; Cui, S.; Qi, W.; Zhang, F.; Sun, X.; Sun, W. A data processing algorithm for multi-wavelength pyrometry-which does not need to assume the emissivity model in advance. Measurement 2015, 67, 92-98. [CrossRef]

7. Wang, H.; Chen, D.; Wang, G.; Long, Y.; Luo, J.; Liu, L.; Yang, Q. Measurement technology for material emissivity under high temperature dynamic heating conditions. Measurement 2013, 46, 4023-4031. [CrossRef]

8. Fu, T.; Tan, P.; Pang, C.; Zhao, H.; Shen, Y. Fast fiber-optic multi-wavelength pyrometer. Rev. Sci. Instrum. 2011, 82, 064902. [CrossRef] [PubMed]

9. Fu, T.; Liu, J.; Duan, M.; Zong, A. Temperature measurements using multicolor pyrometry in thermal radiation heating environments. Rev. Sci. Instrum. 2014, 85, 044901. [CrossRef] [PubMed]

10. Gardner, J.; Jones, T.; Davies, M. A six-wavelength radiation pyrometer. High Temp. High Press. 1981, 13, 459-466.

11. Hiernaut, J.-P.; Beukers, R.; Heinz, W.; Selfslag, R.; Hoch, M.; Ohse, R. Submillisecond six-wavelength pyrometer for high-temperature measurements in the range 2000 to 5000K. High Temp. High Press. 1986, 18, 617-625.

12. Radousky, H.; Mitchell, A. A fast uv/visible pyrometer for shock temperature measurements to 20,000K. Rev. Sci. Instrum. 1989, 60, 3707-3710. [CrossRef]

13. Levendis, Y.A.; Estrada, K.R.; Hottel, H.C. Development of multicolor pyrometers to monitor the transient response of burning carbonaceous particles. Rev. Sci. Instrum. 1992, 63, 3608-3622. [CrossRef]

14. $\mathrm{Ng}$, D.; Fralick, G. Use of a multiwavelength pyrometer in several elevated temperature aerospace applications. Rev. Sci. Instrum. 2001, 72, 1522-1530. [CrossRef]

15. Liang, M.; Sun, B.J.; Sun, X.G.; Xie, J.Y.; Yu, C. Development of a new fiber-optic multi-target multispectral pyrometer for achievable true temperature measurement of the solid rocket motor plume. Measurement 2017, 95, 239-245. [CrossRef]

16. Yuan, G.; Fan, Z.; Sun, X.; Dai, J. Approach method based on brightness temperature for multi-spectral thermometer, in: International Symposium on Instrumentation Science and Technology. Int. Soc. Opt. Photonics 2008, 713309. [CrossRef]

17. Dai, J.; Sun, X.G.; Lu, X.D.; Cong, D. Theory and Practice of Multi-Spectral Thermometry; Higher Education Press: Beijing, China, 2002; p. 75.

18. Sun, X.G.; Yuan, G.B.; Dai, J.M.; Chu, Z.X. Processing method of multi-wavelength pyrometer data for continuous temperature measurements. Int. J. Thermophys. 2005, 26, 1255-1261. [CrossRef]

19. Hamamatsu. Data Sheet of S1336-5BK[DB/OL]. Available online: http://www.hamamatsu.com.cn/product/ 17583.html (accessed on 5 March 2019). 
20. Sun, X.; Zhao, W.; Yuan, G.; Dai, J. Methods of data processing in multi-wavelength thermometry. J. Harbin Inst. Technol. 2006, 13, 421-426.

21. Sun, K.; Sun, X.; Yu, X. Development of Multi-Spectral Thermometer for Explosion Flame True Temperature Measurement. Spectrosc. Spectr. Anal. 2013, 33, 1719.

(c) (

(C) 2020 by the authors. Licensee MDPI, Basel, Switzerland. This article is an open access article distributed under the terms and conditions of the Creative Commons Attribution (CC BY) license (http://creativecommons.org/licenses/by/4.0/). 